\title{
Barriers and Drivers to Sustainable Sea Fishery Management in Togean National Park-Sulawesi, Indonesia
}

\author{
Muslimin ${ }^{1, *}$, Nudiatulhuda Mangun ${ }^{2}$, Elimawaty Rombe ${ }^{2}$, Edhi Taqwa $^{1}$, \\ Maskuri Sutomo $^{1}$, Suryadi Hadi ${ }^{1}$
}

\author{
${ }^{1}$ Department of Management, Tadulako University, Palu, Indonesia \\ ${ }^{2}$ Department of Economics, Tadulako University, Palu, Indonesia \\ *Corresponding Author. Email: muslimin hasan@untad.ac.id
}

\begin{abstract}
Coastal areas and small islands have great potential resources that need to be protected and used for the people's greatest benefits, so they need to be established both in social, economic, cultural, environmental, and as a buffer for the sovereignty of the country. The goal of this study is to identify in the Togean Islands, Tojo Una-Una Regency, Central Sulawesi Province, Indonesia, items that are barriers and driving factors for sustainable management of sea fishing. The benefit of this research area is becoming a national park that contains exceptional marine resources. Interviews with a range of fishermen, traders, government and others. This article describes the findings of driver recognition that can promote the elimination of barriers in the management of sea fishing in the Togean Islands. The results of this study can be used as a guide when defining obstacle es and catalysts in the management of sustainability of marine fisheries. This will help to define and prepare the best approach for sustainable management of fisheries at sea.
\end{abstract}

Keywords: Sustainable, Sea Fishery Management, Togean Island

\section{INTRODUCTION}

The laws and regulations of the Republic of Indonesia, No. 27 of 2007 concerning the management of coastal areas and small islands as amended into Law no. $1 / 2014$ that coastal areas and small islands have great potential resources that need to be preserved and utilized for the greatest prosperity of the people, so that it needs to be developed both in social, economic, cultural, environmental aspects and as a buffer for the nation's sovereignty [1]. The challenges faced in maintaining sustainability in coastal areas are increasing population and improving the quality of human life. This pressure causes the threat of the provision of support services for human life [2]. Globally, fisheries in the world have decreased since the 1960s to 2000 [3]. However, the market potential for fishery products in small islands is so large that it can become one of the drivers of economic growth, both locally, regionally and nationally.

On the other hand, small islands are still classified as isolated areas compared to the mainland and are at risk from the impact of environmental change [4]. Small island has a very high risk because it has marginalization and insularity [5]. The small island has fishery resources which are a source of livelihood for the people who live there. When threats and environmental degradation increase, this condition will have an impact on society from a social and economic aspect [6]. Therefore, it is necessary to make use of small islands to reduce development inequality between regions and social disparities between community groups.

Currently, research on the economic potential of the fisheries sector on small islands is still rare. Meanwhile, small islands can function as areas that can connect one area to another. This function will help accelerate the distribution of fishery products between regions. This acceleration of distribution will improve supply chain performance, particularly fish products, so that it will have a positive impact on every stakeholder of the fish supply chain. Therefore, it is very important to study the economic potential in the fisheries sector on small islands in Central Sulawesi. The Togean Islands have 6 large islands and 60 other islands, including the category of small islands. The large islands in the Togean Islands 
have been inhabited by the community while most of the other small islands are not yet inhabited by the community. The positive impact of implementing sustainable seafood on small islands can be a high focus because it will have a large impact on the environment, social and economy.

\section{LITERATURE REVIEW}

\subsection{The History of Sustainable Seafood Activities}

The issue of Sustainable Seafood developed in the 90 s was raised by several non-governmental organizations which stated that the government had ignored its sense of responsibility in managing marine capture fisheries [7]. Criticism regarding the issue of the seafood supply chain continues with the hope that the government will be involved in reducing overfishing [8]. Even though the criticism from these NGOs includes the environmental movement, they are basically supported by large companies in implementing market-based neoliberalism [9]. Gutierrez and Morgan state that the implementation of sustainable seafood has developed rapidly in several countries by requiring the implementation of procurement policies as rules that must be followed by retailers [10]. The sustainable seafood movement has positioned themselves as a nongovernmental organization that always improves the capability of sustainable capture fisheries through the supply chain. This movement really depends on their ability to face changing challenges, including issues of authority, sharing responsibility and developing markets.

\subsection{Fish Supply Chain Management}

Fishery is a sector that can help the process of implementing food security [11]. Supply chain management involves upstream activities represented by suppliers and downstream activities represented by consumers. The implementation of the fish supply chain involves several entities with a high level of complexity. The fish supply chain consists of fishermen, collectors, traders, processing industries and consumers. The fish supply chain is mutually integrated with the support of high trust from all parties involved [12]. Openness in sharing information can add value to each entity in the supply chain system for fish commodities. Supply chain efficiency and performance will increase because a supply chain management strategy will be able to reduce excess inventory, increase quality and reduce costs [13]. Information technology cannot be separated from supply chain management activities because it can be used as a tool for collaboration networks and information sharing so that performance can be achieved [14]. The benefits obtained from the use of information technology can reduce the costs of communication and information processing [15]. Fish supply chain management is almost similar to the supply chain for other commodities. The thing that distinguishes it is the product characteristics that involve a series of processes or activities in the waters to catch fish which then require further activities, namely maintaining the freshness of the fish up to the hands of the end consumer.

\section{METHOD}

This paper is prepared based on research results by defining the management of the fishery supply chain in the Togean Islands, Tojo Una-Una Regency, Central Sulawesi Province, Indonesia. The reason this area was chosen is because the region consisted of about 66 islands and was rich with biodiversity. The theoretical approach used in this study involves use of qualitative analysis with a descriptive approach where the researcher is the main instrument. This descriptive method is achieved by defining the conditions that exist at the location of the analysis, which is then carried out by drawing general conclusions from the collected data. This research has been conducted to examine and explore environmental, economic, and social trends in the management of sea fisheries. Interviewed subjects included: fishermen, traders, hauliers, government, and other relevant parties. Researchers collected data through direct interviews and observations in order to obtain information on the Togean Islands relevant to sustainable sea fishery management. Semi structure interview was prepared based on literature review and previous research. This research was carried out in the new normal after the corona virus pandemic.

\section{RESULTS AND DISCUSSIONS}

\subsection{Description of Togean Islands}

The Togean Islands are hidden in Tomini Bay, precisely in Central Sulawesi. The location of this island is indeed remote. The Togean Islands stretch out over an area of approximately 102 kilometers with a land area of about $755 \mathrm{~km}^{2}$, and have about 66 island clusters scattered across the middle of Tomini Bay. This archipelago is administratively located in the regency of Tojo Una-una. This place is often known as Togian Island or Togean Islands National Park. This place has a very charming underwater beauty. Due to the amazing natural wealth under the sea, the local government is always trying to protect the natural preservation of this Togean island. The Togean Islands are listed in the list of the Coral Triangle region of Indonesia - the Philippines. Togean Island is one of the places that has underwater biodiversity of all world biodiversity. 
This research seeks to collect the most recent data but is hampered by the COVID-19 pandemic so that the fisheries data obtained is still based on data from the past decade. Based on statistical data from Central Bureau of Statistics (BPS) [16], the number of fishermen in Tojo Una-Una Regency was 3,664 with a total production of $12,058.78$ tons with a value of IDR $156,957,987.30$ [17]. The number of fishermen in 2013 increased by 1000 efficiency of fishermen at the local level compared to the regional level. Their research concluded that Tojo UnaUna Regency, whose sea waters are dominated by pelagic fish, need to support fishermen with the help of technology or infrastructure to support the utilization of coastal resources. This paper identifies several barriers that influence sustainable sea fishery management in Togean Islands. Firstly, the law of fishing has not been

Table 1. Barriers and Drivers Sustainable Sea Fishery Management

\begin{tabular}{|l|l}
\hline Barriers & Drivers \\
\hline The fishing law is not yet optimal & $\square$ Coral reef ecosystems \\
$\square$ Fishing practices utilize equipment which is not & $\square$ Great fisheries potential \\
environmentally friendly, for example potassium, trawl & $\square$ Strategic geographical position \\
uses & $\square$ The inherent marine culture \\
$\square$ Capacity building for groups & $\square$ Potential Market \\
$\square$ Low quality fisheries human resources & $\square$ Shorter distribution channel \\
$\square$ Low fishing productivity & $\square$ Collective action among fishermen \\
$\square$ Lack of fishery facilities and infrastructure (uneven tires & $\square$ Regional Development Priorities \\
$\quad \begin{array}{l}\text { for hosting equipment) } \\
\text { Pollution and damage to aquatic ecosystems }\end{array}$ & \\
\hline
\end{tabular}

from 2012. An illustration of the number of fishermen, production and value generated can be seen in the following explanation. Walea Kepulauan District has very large fishermen, namely 948 people with a total production of 1047 tons with a value of IDR $21,220,860$. The number of fishermen in Una -una subdistrict reaches 476 people with a production level of 802.15 tons with a value of Rp. 16,091,430. Togean subdistrict which has 394 fishermen can only reproduce 759.41 tonnes with a value of IDR 15,116,310.

Meanwhile, Walea Big District with 226 fishermen can produce 1106.23 tons of fish with a value of IDR $16,592,860$. Based on data from the Central Bureau of Statistics (BPS) in 2015, it was found that the number of districts had increased by two, namely Batudaka and Talatako. The highest number of outboard motorboats in the Togean Islands is in Talatako Subdistrict, with 368 units, while the non-motorized boats in this sub-district are 140 units. The second largest number of boats is in Togean District with 335 units while the boats without motor are 114 units. Batudaka Subdistrict also has the number of outboard motorboats in third place with 315 units and 12 units without motorboats. Walea Kepulauan Subdistrict has 284 outboard motorboats with 50 nonmotorized boats. Meanwhile, two other sub-districts, namely Una-Una and Walea Besar, each have 211 and 166 units of outboard motor boats, while 6 units of motorbikes without boats in Una-Una Subdistrict and none in Walea Besar District.

\subsection{Barriers}

Generally, fishermen in the Togean Islands use simple fishing gear so that the utilization of marine and coastal natural resources is still categorized as a small scale. The fishing gear they use is such as fishing rods, nets, traps and charts. This has an impact on the low optimal yet, it greatly affects fishermen's activities to use certain equipment which can harm the ecosystem in fishing. Lack of supervision from related officials is still lacking so law enforcement is very important in resolving this problem. Secondly, plastic waste in the Togean Islands is a major issue faced by fishermen because it greatly disturbs the fish ecosystem. Increasing public awareness is still not optimal because people are still continuously disposing of garbage, especially plastic waste in marine waters. Thirdly, the increasing use of equipment that is not environmentally friendly, such as potassium and trawling. Based on the interviews conducted, it was obtained data that generally fishermen still perform anesthetics using potassium when fishing. The negative impact is very large because small fish also die which then affects the fish population in these waters. Fourthly, the capacity of fishermen groups is not optimal because there are still many fishing groups that are not active.

The fishermen's group will be active when they get information that assistance will be disbursed to them. Increasing the capacity of fishermen groups can support the implementation of sustainable fisheries in the Togean Islands. They could become agents of change in protecting the aquatic environment and conducting fisheries surveillance. Fifth, the training of fishermen must be continuously improved by the local government because the high knowledge they have can help implement sustainable fisheries. People who live in the Togean Islands really expect marine products to support their lives. To manage small scale fisheries sustainably by maintaining local wisdom owned by fishermen through user regulation, types of fishing gear, and protection of certain species. The low productivity of fishermen which is still low and on the other hand the higher demand for seas encourages them to carry out 
activities that can damage the environment by giving potassium into the sea or using trawlers. Marine protected areas can assist fisheries management in a sustainable manner. Making marine conservation can maintain the sustainability and increase of fish stocks [18].

\subsection{Drivers}

Several factors that can impact on the sustainable sea fishery management in Togean Islands. First, the waters of the Togean Islands also have all types of coral reefs in the world, including: fringing reefs, barrier reefs, patch reefs and atolls. Togean endemic reefs, namely Acropora togeanensis. The recorded coral reef fish were 596 fish species belonging to 62 families, including Paracheilinus togeanensis and Ecsenius sp, which are strongly suspected of being Togean endemic. In addition, 555 species of molluscs from 103 families, 336 types of Gastropods, 211 species of Bivalves, 2 types of Ce phalopods, 2 types of Scaphopod and 4 types of Chiton were found [19]. Second, the Togean Islands are located in the middle of Tomini Bay, in a transverse position from west to east. To the south and west, separated from the deep ocean, the Togean islands are bordered by the mainland of the island of Sulawesi. Meanwhile, to the north, the Togean islands are bordered by the mainland of the island of Sulawesi, which is part of the Gorontalo province. The total land area of the Togean islands is approximately $755.4 \mathrm{~km} 2$ or about 75,000 ha. The spatial form of the Togean islands is a series of 7 main islands extending from west to east, namely the islands of Batudaka, Togean, Talatakoh, Una una, Malenge, Walea Kodi, and Walea Bahi. The islands are surrounded by several smaller islands, as well as dozens of uninhabited islets that are more like rocks sticking out of the sea. Third, the large potential of fisheries in the Togean Islands encourages people to live and go to sea to look for fish so that they can generate income for their families. The ability to pass through from generation to generation is a fortune that the local community has. However, this marine culture must be supported with high awareness so that they can use the sea as a source of income wisely. In other words, the current community must maintain the sustainability of marine fisheries for their children and grandchildren in the future

Fourth, capture fisheries product market is very large, both locally, regionally, nationally and internationally. Market demand increases every year along with increasing population. An increase in demand can affect the increase in activities upstream of the capture fish supply chain. If consumers want greater transparency on the origin of the fish they will consume, this can be a driver to sea fishery sustainability. Fifth, the distribution of catch-right products involves various entities so that the supply chain is quite complex. Reducing short fish distribution channels can help improve the efficiency of fish product distribution to serve local and regional and national community needs. The government needs to be involved in building the capacity of fishermen groups so that their products can be marketed directly to local consumers with high quality fish. Meanwhile, the distribution of fish to regional and national levels can also respond quickly to consumer needs. Six, the government has motivated fishermen to group together so that government assistance can be distributed easily and precisely. The formation of fishermen groups is intended so that fishermen can help one another.

Collaboration among fishermen can increase so that their bargaining position is also increased [20]. Fishermen groups like this can be agents for the sustainability of marine fisheries. Knowledge about marine conservation obtained from training held by the government or NGOs can help preserve marine ecosystems. Seven, regional development can have a major impact on the sustainability of marine fisheries. Regional development planning is needed to add marine conservation items as a priority with the aim of sustainable small island development. The consistency of the sustainable development of small islands by maintaining marine and land conservation in them can help the survival of the ecosystem of fish and other fauna. To identify and understand the sustainability of marine fish supply chain management, it is necessary to identify the things that are the barriers and drivers in the Togean islands. These barriers and drivers are analyzed for each entity in the supply chain of marine fish. The barriers can be seen in the following table.

\section{CONCLUSIONS}

The development of small islands must pay attention to the sustainability aspects of the activities of the people who live in small islands. The development of small islands will greatly impact the economic and social environment in these islands. Utilization of marine water resources must follow the protocol that has been issued by the government so that sustainability can be continuously maintained. This paper focuses on the things that become barriers and drivers in realizing sustainable sea fishery management. The government should conduct intensive discussions with other stakeholder elements, such as NGO, so that the sustainability of sea fisheries on small islands can be optimized.

An institutional approach such as customary institutions can be an effective way to reduce the negative impact of overuse of marine waters. The high awareness of customary stakeholders can be an impetus for communities around small islands not to carry out activities that can damage marine ecosystems, for example throwing plastic waste into the sea. It is hoped that the results of the preparation of this paper can become a reference in preparing a sustainable development plan for small islands. The findings in this paper should be further analyzed by applying another research approach. 


\section{AUTHORS' CONTRIBUTIONS}

All authors discussed the results and contributed to the final manuscript.

\section{ACKNOWLEDGMENTS}

The authors would like to express our appreciation to Tadulako University for funding this research under Graduate Research Grant of Tadulako University.

\section{REFERENCES}

[1] I. Government., "Undang-Undang Republik Indonesia Nomor 27 Tahun 2007.," Indonesian Government, Jakarta, 2007.

[2] J. Jackson, M. Kirby, W. Berger, K. Bjorndal, B. Bourque, R. Bradbury and R. Warner, "Historical overfishing and recent collapse of coastal ecosystems," Science, pp. 629-633, 2001.

[3] R. Myers and B. Worm, "Rapid worldwide depletion of predatory fish communities.," Nature, pp. 280-283, 2003.

[4] A. Cherian, "Linkages between biodiversity conservation and global climate change in small island developing state (SIDS)," Natural Resources Forum, pp. 128-131, 2007.

[5] P. Van Beukering, L. Brader, E. Tompkins and E. Mackenzie, "Valuing the environment in small islands: An environmental economics toolkit Peterborough.," Joint Nature Conservation Committee, 2007.

[6] M. Scheffer, S. Szabo, A. Gragnani and E. Van Nes, "Floating plant dominance as a stable state," Proc.Natl.Acad Sci USA, pp. 403-415, 2003.

[7] M. Sutton and L. Wimpee, "Towards sustainableseafood: the evolution of a conservation movement.," Seafood ecolabelling: principles and practice, pp. 403-415, 2008.

[8] J. Jacquet, J. Hocevar, S. Lai, P. Majluf, N. Pellentier and T. Pitcher, "Conserving wild fish in a sea of market-based effort.," Oryx, vol. 44, no. 45, 2009.

[9] J. Konefal, “Governing sustainability transitions: Multi-stakeholder initiatives and regime change in United States Agriculture," Sustainability, pp. 612622, 2015.

[10] A. Gutierrez and S. Morgan, "Movement in the US and UK capture fisheries supply chain and fisheries governance.," Front.Mar.Sci, 2015.

[11] M. L and M. Rosa, "Sustainable fishing?Ecological footprint analysis of an artisanal fishing organization.," The open environmental research journal, 2019.

[12] V. Kannan and K. Tan, "The impact of supplier selection and buyer-supplier enggagement on relationship and firm performance," International journal of physical distribution \& logistics management, 2006.

[13] S. Qrunfleh and M. Tarafdar, "Supply chain information system strategy:Impacts on supply chain performance and firm performance.," International journal of production economics, $\mathrm{pp}$. 340-350, 2014.

[14] B. Huo, Y. Qi, Z. Wang and X. Zhao, "The impact of supply chain integration on firm performance(the mdoerating role of competitive strategy)," Supply chain management:An international journal, pp. 369-384, 2014.

[15] E. Brynjolfsson and L. Hitt, "Beyond Computation: Information Technology, Organizational Transformation and Business Performance," Journal of Economics Perspective, pp. 23-48, 2000.

[16] I. C. B. o. Statistics, "Tojo Una-Una Dalam Angka," BPS, Ampana, Sulawesi Tengah, Indonesia, 2013.

[17] I. C. B. o. Statistics, "Tojo Una-Una Dalam Angka," BPS, Ampana, Sulawesi Tengah, Indonesia, 2009.

[18] K. Gjerde, L. Reeve, H. Harden-Davies, J. Ardron, R. Dolan, C. Durussel, ...... and T. Wilhelm, "Protecting earth's last conservation frontier:scientific, management and legal priorities for MPAs beyond national boundaries," Aquatic conservation marine and freshwater ecosystems, vol. 26, no. S2, pp. 45-60, 2016.

[19] G. Allen and S. McKenna, "A marine rapid assessment of the Togean and Banggai Island, Sulawesi Indonesia. Washington D.C. RAP Bulletin of Biological Assessment 20. Center for Applied Biodiversity Science, Conservation International," 2001.

[20] E. Rombe, M. Mubaraq, S. Hadi, R. Adriansyah and G. Vesakha, "Barriers and drivers for applying fish traceability system in emerging market," International journal of engineering \& technology, vol. 4, no. 15, p. 262, 2018. 